Pease, P. (1969). Bacterial L-forms in the blood and joint fluids of arthritis subjects. Annals of the Rheumatic Diseases, 28, 270-274.

Pease, P. (1970). Morphological appearances of a bacterial L-form growing in association with the erythrocytes of arthritic subjects. Annals of the Rheumatic Diseases, 29, 439-444.

Pease, P. (1974). Identification of bacteria from blood and joint fluids of human subjects as Bacillus licheniformis. Annals of the Rheumatic Diseases, 33, 67-69.

Roberts, D. E. (1964). L-phase bacterial forms associated with infectious synovitis in chickens and turkeys. Research in Veterinary Science, 5, 441-449.

Tedeschi, G. G., Amici, D., and Santarelli, I. (1975). L- and conventional forms of micrococci in the circulating blood of thrombocytopenic patients. Experientia, 31, 1088-1089.

\section{Effect of anti-inflammatory agents on serum gastrin concentrations}

Sir,

We were interested in the paper by Rooney et al. (1976) showing that the raised serum immunoreactive gastrin concentration, which is frequently found in patients with rheumatoid arthritis, is not modified by 14 days' administration of anti-inflammatory drugs (aspirin, indomethacin, phenylbutazone, tetracosactrin, or ascorbic acid). Other workers have reported increased basal and/or mealstimulated serum gastrin levels after chronic corticosteroids or corticotrophin treatment, both in the dog (Watson et al., 1973) and in man (Raptis et al., 1976), while the basal serum gastrin concentration was not modified after acute parenteral administration of hydrocortisone (Watson et al., 1973; Giordano and Marugo, 1974) or prednisolone (Raptis et al., 1976). No data are available on the effects of acute administration of nonsteroidal anti-inflammatory drugs on serum gastrin levels. Therefore, we have evaluated the serum gastrin concentration after acute parenteral administration of phenylbutazone, lysine-acetylsalicylate, and hydrocortisone.
Twenty-seven healthy males aged 26-51 years volunteered for study. Each drug was administered after an overnight fast to 9 subjects as follows: hydrocortisone $100 \mathrm{mg}$ or lysine-acetylsalicylate $2 \mathrm{~g}(1.8$ acetylsalicylic acid) by rapid intravenous injection; phenylbutazone $600 \mathrm{mg}$ intramuscularly. The serum gastrin concentration was evaluated by the radioimmunoassay method before and 15,30,45, 60, and 90 minutes after treatment. The Table shows that the mean serum basal gastrin levels were not significantly modified by any drug.

Present data confirmed that acute hydrocortisone administration does not affect gastrin secretion and, together with the study by Rooney et al. (1976), show that acetylsalicylic acid and phenylbutazone fail to increase serum gastrin after acute as well as chronic treatment.

\section{Guglielmo Curtarelli, Roberto Caldara, and LUIGI BIERTI \\ 2nd Department of Medicine, Fatebenefratelli Hospital, 23 Corso di Porta Nuova, 20121 Milan, Italy.}

\section{References}

Giordano, G., and Marugo, M. (1974). Comportamento della gastrina ematica nell'uomo dopo carico endovenoso di cortisolo. Bollettino della Società Italiana di Biologia Sperimentale, 50, 1905-1910.

Raptis, S., Berger, L., Dollinger, H. C., Fazekas, A. T., and Pfeiffer, E. F. (1976). Hypergastrinemia induced by glucocorticoid and corticotropin treatment in man. American Journal of Digestive Diseases,. 21, 376-380.

Rooney, P. J., Grennan, D. M., Sturrock, R. D., Brooks, P. M., and Dick, W. C. (1976). Serum immunoreactive gastrin: specificity for rheumatoid arthritis, bimodality of distribution, and failure of effect of anti-inflammatory drugs. Annals of the Rheumatic Diseases, 35, 40-45.

Watson, L. C., Reeder, D. D., and Thompson, J. C. (1973). Effect of hydrocortisone on gastric secretion and serum gastrin in dogs. Surgical Forum, 24, 354-356.

Table Effect of acute administration of anti-inflammatory agents on serum gastrin concentration in normal subjects $($ mean \pm SEM)

\begin{tabular}{|c|c|c|c|c|c|c|c|c|}
\hline \multirow[t]{2}{*}{ Treatment } & \multirow[t]{2}{*}{ No. of subjects } & \multicolumn{7}{|c|}{ Time (min) } \\
\hline & & -15 & 0 & 15 & 30 & 45 & 60 & 90 \\
\hline $\begin{array}{l}\text { Phenylbutazone } \\
\text { Lysine-acetylsalicylate } \\
\text { Hydrocortisone }\end{array}$ & $\begin{array}{l}9 \\
9 \\
9\end{array}$ & $\begin{array}{l}72 \pm 7 \\
80 \pm 5 \\
75 \pm 7\end{array}$ & $\begin{array}{l}71 \pm 8 \\
78 \pm 7 \\
73 \pm 7\end{array}$ & $\begin{array}{l}73 \pm 8 \\
80 \pm 8 \\
75 \pm 6\end{array}$ & $\begin{array}{l}76 \pm 9 \\
82 \pm 7 \\
79 \pm 10\end{array}$ & $\begin{array}{l}77 \pm 6 \\
80 \pm 9 \\
76 \pm 9\end{array}$ & $\begin{array}{l}70 \pm 9 \\
83 \pm 10 \\
78 \pm 7\end{array}$ & $\begin{array}{l}73 \pm 9 \\
79 \pm 8 \\
78 \pm 9\end{array}$ \\
\hline
\end{tabular}

